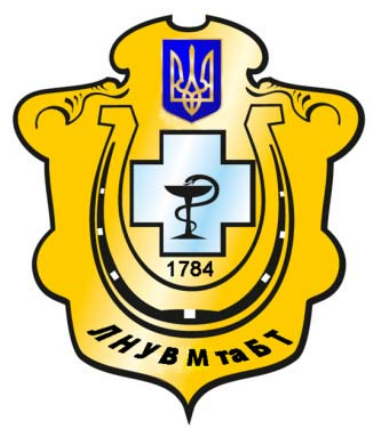

Науковий вісник Львівського національного університету ветеринарної медицини та біотехнологій імені С.3. Гжицького

Scientific Messenger of Lviv National University of Veterinary Medicine and Biotechnologies named after S.Z. Gzhytskyj

doi:10.15421/nvlvet7025

ISSN 2413-5550 print

ISSN 2518-1327 online

$\underline{\text { http://nvlvet.com.ua/ }}$

УДК 637.12:619:618.19-002

\title{
Бактеріальне забруднення молока за різних температур i термінів зберігання
}

\author{
Н.M. Зажарська \\ zazharskayan@gmail.com
}

Дніпропетровський державний аграрно-економічний університет, вул. Ворошилова, 25, м. Дніпро́, 49000, Украӥна

Дослідження проведені у лабораторї контролю якості молока LILCO, м. Сюржер, Франція. Для першого досліду було відібрано 24 проби збірного охолодженого козиного молока, яке протягом 2 - 3 годин транспортувалося за різних температур. Потім всі проби зберігалися добу за температури $4{ }^{\circ} \mathrm{C}$. Показники бактеріального забруднення, жиру, білку, температури замерзання, кількості соматичних клітин, сечовини були однаковими за різних температур транспортування проб молока. Відмічали велику кількість соматичних клітин (>2000 тис/мл) при малому бактеріальному забрудненні (19,6 $\times 10^{3} \mathrm{KУO/мл)} \mathrm{козиного} \mathrm{молока.} \mathrm{Проби} \mathrm{можуть} \mathrm{бути} \mathrm{доставлені} \mathrm{у} \mathrm{лабораторію} \mathrm{протягом} 2$ - 3 годин за температури 2 , 10 або $20{ }^{\circ} \mathrm{C}$, якщи молоко відразу після доїння охолоджується $i$ зберігається в танку за температури $4{ }^{\circ} \mathrm{C}$.

Також були досліджені 10 проб коров'ячого молока (неохолоджене - через 3 години після доӥння, охолоджене - через добу). Бактеріальне забрудненням молока, яке було охолоджене $і$ зберігалось 1 добу за температури $4^{\circ} \mathrm{C}$ менше в 4,6 рази $(P<0,01)$, ніж молока неохолодженого, дослідженого через 3 години після доӥння. Це доказує, що відповідність бактеріального забруднення молока до європейських вимог (до 100 тис. КУО/мл) можлива тільки при охолодженні молока в потоиі до $4^{\circ} \mathrm{C}$ відразу після доӥння $і$ зберігання його у танку-охолоджувачі.

Ключові слова: козине молоко, коров'яче молоко, бактеріальне забруднення, кількість соматичних клітин, температура охолодження, первинна обробка, транспортування, зберігання молока.

\section{Бактериальное обсеменение молока при различных температурах и сро- ках хранения}

\author{
Н.Н. Зажарская \\ zazharskayan@gmail.com
}

Днепропетровский государственный аграрно-экономический университет, ул. Ворочилова, 25, г. Днепр, 49000, Украина

Исследования проведены в лаборатории контроля качества молока LILCO, г. Сюржер, Франиия. Для первого опыта было отобрано 24 пробы сборного охлажденного козьего молока, которое в течение 2 - 3 часов транспортировалось при различных температурах. Затем все пробы хранились при температуре $4{ }^{\circ} \mathrm{C}$ сутки. Показатели бактериального обсеменения, жира, белка, температуры замерзания, количества соматических клеток, мочевины были одинаковыли при различных температурах транспортировки проб молока. Отмечали большое количество соматических клеток (>2000 тыс./мл) при малом бактериальном загрязнении $\left(19,6 \times 10^{3} \mathrm{KOE} /\right.$ мл) козьего молока. Пробы молока могут быть доставлены в лабораторию в течение 2 - 3 часов при температуре 2,10 или $20^{\circ} \mathrm{C}$, если молоко сразу после дойки охлаждается и хранится 8 танке при температуре $4{ }^{\circ} \mathrm{C}$.

Также были исследованы 10 проб коровьего молока (неохлажденное - через 3 часа после доения, охлажденное - через день). Бактериальное обсеменение молока, которое было охлаждено и хранилось 1 сутки при температуре $4{ }^{\circ} \mathrm{C}$ меньше в 4,6 раза $(P<0,01)$, чем молока неохлажденного, исследованного через 3 часа после доения. Это доказывает, что соответ-

Citation:

Zazharska, N.M. (2016). Bacterial contamination of milk at different temperatures and shelf life. Scientific Messenger LNUVMBT named after S.Z. Gzhytskyj, 18, 3(70), 108-111. 
ствие бактериального обсеменения молока европейским требованиями (до 100 тьс. КОЕ/мл) возможно только при охлаждении молока в потоке до $4{ }^{\circ} \mathrm{C}$ сразу после доения и хранении его в танке-охладителе.

Ключевые слова: козье молоко, коровье молоко, бактериальное обсеменение, количество соматических клеток, температура охлаждения, первичная обработка, транспортировка, хранение молока

\title{
Bacterial contamination of milk at different temperatures and shelf life
}

\author{
N.M. Zazharska \\ zazharskayan@gmail.com \\ Dipropetrovsk state agrarian-economic university,
Voroshilov Str., 25, Dnipro, 49000, Ukraine
}

Research was conducted in the laboratory LILCO, Surgères, France. For the first experiment, 24 samples of cooled bulk tank goat milk were selected be transported within $2-3$ hours at different temperatures. Then all samples were stored day at $4{ }^{\circ} \mathrm{C}$. The indicators of bacterial contamination, fat, protein, freezing point, somatic cell count, urea were similar for different temperatures of transporting milk samples. Noted the big somatic cell count $>2000$ thousand / ml) at low bacterial contamination (19,6 $\times$ $10^{3} \mathrm{CFU} / \mathrm{mL}$ ) of goat milk. Samples of milk can be delivered to the laboratory for 2-3 hours at a temperature of 2, 10 or $20{ }^{\circ} \mathrm{C}$ if the milk immediately after milking cooled and stored in a tank at $4{ }^{\circ} \mathrm{C}$.

10 samples of cow's milk (non-cooled - 3 hours after milking, cooled-after a day) were also examined. Bacterial contamination of milk which has been cooled and being stored one day at $4{ }^{\circ} \mathrm{C}$ was in 4.6 times less $(P<0.01)$ than non-cooled milk, analyzed in 3 hours after milking. This proves that bacterial contamination of milk in Ukraine accordance with European requirements (up to 100 thousand. CFU/ml) is possible only when rapid cooling of milk after milking to $4{ }^{\circ} \mathrm{C}$ and storing it in the cooling tank.

Key words: goat milk, cow milk, bacterial contamination, somatic cell count, the temperature of the cooling, primary processing, transportation, shelf life of milk.

\section{Вступ}

Основну роль у бактеріальному забрудненні молока від здорових тварин відіграють санітарні умови його отримання і первинна обробка, у т.ч. охолодження (Yatsenko et al., 2016). Впливає на якість сировини також температура молока під час приймання на переробні підприємства. За вимогами існуючого ДСТУ 3662-97 температура молока гатунку «Екстра» повинна бути до $6{ }^{\circ} \mathrm{C}$, «Вищого» - до $8^{\circ} \mathrm{C}$ (DSTU 3662-1997). Для визначення показників молока відбирають проби для лабораторного аналізу, за температури $2-5^{\circ} \mathrm{C}$ проби можуть зберігатися протягом двох діб (Yakubchak et al., 2012). Іспанськими вченими виявлено, що консервування i тривале зберігання значно змінюють показники кількості соматичних клітин, також температура замерзання стає нижчою в консервованих пробах, ніж в пробах свіжого молока (Sánchez et al., 2005). Іншими вченими визначено, що охолодження і заморожування суттєво не змінюють кислотність, термостійкість, густину, вміст жиру і білку, сухих речовин і лактози, але відмічено зменшення кількості соматичних клітин у замороженому молоці в порівнянні зі свіжим і охолодженим (Dutra et al., 2014). За висновками Sierra D. та ін. для визначення мікробного забруднення методом проточної цитометрії на BactoScan можливе зберігання проб козиного молока, консервованих азідіолом, при $10{ }^{\circ} \mathrm{C}$ до 24 год. або при $4{ }^{\circ} \mathrm{C}$ - до 11 днів після відбору; використання бронополу не рекомендовано (Sierra et al., 2009). Вітчизняні науковці пропонують додавати лізоцим в молоко для збільшення терміну зберігання i поліпшення функціональних властивостей питного пастеризованого молока (Mashkin et al., 2013). На думку Mohamed H. та ін. застосування лактопероксідазної системи ензимів (LPS) пригнічує ріст і розмноження мікроорганізмів і подовжує термін придат- ності козиного молока в умовах Судану (дослідження проводились в різні періоди лактації нубійських кіз за температури зберігання молока $5 \pm 2,13 \pm 2,25 \pm 2$ i $37 \pm 2{ }^{\circ} \mathrm{C}$ ) (Mohamed et al., 2016).

Мета $і$ завдання дослідження - визначити бактеріальне забруднення та фізико-хімічні показники молока за різних температур і термінів зберігання.

\section{Матеріал і методи досліджень}

Дослідження проводились у лабораторії LILCO (Laboratoire Interprofessionnel Laitier du Centre Ouest Міжпрофесійна лабораторія молока центру і заходу), м. Сюржер, Франція, наприкінці 2014 року підчас стажування. LILCO - одна 316 лабораторій з контролю якості молока у Франції, обслуговує в регіоні близька 3500 фермерів, які утримують корів и 1700 фермерів, які отримують молоко від кіз. У лабораторії за день досліджують 16 тисяч проб молока. В залежності від результатів аналізу за місяць LILCO формує ціну, яку молокопереробне підприємство заплатить фермеру за молоко.

Весь хімічний аналіз молока проводили за допомогою інфрачервоної спектроскопії на приладах FossomaticTM FC i MilkoScanTM FT+. Мікробне забруднення молока визначали методом проточної цитометрії (FOSS Integrated Milk Testung BactoScanFC). За рік лабораторія LILCO проводить аналіз мікробного забруднення близька 200 тисяч проб молока кіз і корів.

Проби відбирали разом з молочним контролером на фермах регіону Пуату-Шарант, Франція. Завданням першого досліду було визначити вплив температури транспортування на мікробіологічні і фізикохімічні показники козиного молока. Проби відбирали 3 танків фермерів, які виробляють від 100 до 3,5 тис. літрів козиного молока, у деяких молоко збирають раз 
в 2 дні, в інших раз в 3 дні. Молоко після доїння було охолоджено і зберігалося у танку-охолоджувачу при температурі $4{ }^{\circ} \mathrm{C}$. У чотирьох фермерів було відібрано по 6 проб збірного охолодженого молока. Протягом 2-3 год. проби молока транспортувалися за різних температур: 2,10 і $20^{\circ} \mathrm{C}$. Потім всі проби були поставлені у холодильник лабораторії LILCO за температури $4{ }^{\circ} \mathrm{C}$ і досліджені наступного дня.

Для другого досліду було відібрано після доїння роботом охолоджене (5 проб) і неохолоджене коров'яче молоко (5 проб). Неохолоджене зберігалось за температури навколишнього середовища $\left(15^{\circ} \mathrm{C}\right)$ i було досліджене через 3 год. після доїння. Охолоджене молоко зберігали за температури $4^{\circ} \mathrm{C}$ протягом 1 доби.

\section{Результати та їх обговорення}

3 таблиці 1 видно, що всі показники козиного молока знаходяться на одному рівні незалежно від температури транспортування проб.

Отже, якщо молоко відразу після доїння охолоджується і зберігається в танку за температури $4{ }^{\circ} \mathrm{C}$, то немає значення при якій температурі проби протягом 2-3 годин будуть доставлені у лабораторію.

Sanchez-Macias D. та ін. вивчали вплив температури і терміну зберігання на кількість соматичних клітин козиного молока за допомогою лічильника клітин DeLaval. Зберігання молока при 4, 21, 36 або $45{ }^{\circ} \mathrm{C}$ знижувало значення показника в порівнянні зі свіжим молоком, тому вчені припускають, що незалежно від температури зберігання, зразки козиного молока не повинні зберігатися протягом більш ніж за 1 год. до вимірювання кількості соматичних клітин пристроєм DeLaval (Sanchez-Macias et al., 2009).

Таблиия 1

Результати аналізу проб збірного козиного молока 3 танків-охолоджувачів, $\mathbf{M} \pm \mathbf{m}, \mathbf{n}=\mathbf{8}$

\begin{tabular}{|c|c|c|c|}
\hline \multirow[t]{2}{*}{ Показники } & \multicolumn{3}{|c|}{$\begin{array}{c}\text { Tемпература транспортування проб } \\
\text { збірного молока }\end{array}$} \\
\hline & $2^{\circ} \mathrm{C}$ & $10^{\circ} \mathrm{C}$ & $20^{\circ} \mathrm{C}$ \\
\hline $\begin{array}{l}\text { Бактеріальне } \\
\text { забруднення, } \\
\times 10^{3} \text { КУО/мл }\end{array}$ & $19,6 \pm 0,9$ & $19,6 \pm 0,8$ & $19,6 \pm 1,0$ \\
\hline Жир, \% & $3,86 \pm 0,04$ & $3,85 \pm 0,04$ & $3,85 \pm 0,04$ \\
\hline Білок, \% & $3,59 \pm 0,01$ & $3,60 \pm 0,02$ & $3,60 \pm 0,01$ \\
\hline $\begin{array}{l}\mathrm{T}^{\circ} \text { замерзання, } \\
{ }^{\circ} \mathrm{C}\end{array}$ & $\begin{array}{l}-0,5513 \\
\pm 0,0011\end{array}$ & $\begin{array}{l}-0,5520 \\
\pm 0,0013\end{array}$ & $\begin{array}{l}-0,5518 \\
\pm 0,0010\end{array}$ \\
\hline $\begin{array}{l}\text { Кількість } \\
\text { соматичних } \\
\text { клітин, тис/мл }\end{array}$ & $2224 \pm 298$ & $2242 \pm 300$ & $2233 \pm 306$ \\
\hline Сечовина, мг/л & $480,6 \pm 27,3$ & $472,8 \pm 27,1$ & $477,1 \pm 28,2$ \\
\hline
\end{tabular}

Молоко було відібрано від козиного стада наприкінці лактації, що пояснює таку велику кількість соматичних клітин, але кількість мікроорганізмів дуже мала (табл.1). Відповідно до ДСТУ 7006:2009 для козиного молока вищого гатунку допускається бактеріальне забруднення до 100 тис. КУО/ $\mathrm{cm}^{3}$ (DSTU 7006:2009). Про відсутність прямої залежності між кількістю соматичних клітин і бактеріальним забрудненням козиного молока вказувалося в більш ранніх власних публікаціях (Zazhars'ka and Ryaba, 2016). Молоко було досліджено через добу, тому що так відбувається у лабораторії - проби, які привозять, зберігають у холодильнику і досліджують наступного дня. За день і вночі водії LILCO збирають проби 3 молокопереробних підприємств, куди їх доставляють водії молоковозів, які збирають молоко у фермерів. Збір молока відбувається не кожного дня, частота залежить від розмірів стада тварин і об'єму танкаохолоджувача фермера. Всі молоковози у Франції обладнані системою забору проб і кожного разу, як молоко з танку-охолоджувача попадає у цистерну, у пластиковий флакон набирається крапельним способом проба молока 60 мл. Водій наклеює стікер 3 номером фермера, ставить пробу у термоконтейнер (температура $2-4{ }^{\circ} \mathrm{C}$ ), привозить на переробне підприємство (Zazharskaya, 2015).

Для контролю повноцінності протеїнової годівлі корів і кіз необхідно мати дані про вміст в молоці білка й сечовини. Вміст останньої дозволяє також зробити висновок про забезпеченість тварин енергією, яка необхідна для синтезу мікробного протеїну в рубці. У випадку іiі нестачі незатребувана кількість аміаку надходить до печінки, де утворюється сечовина (Ladika et al., 2014).

Результати дослідження коров'ячого молока представлені на рис. 1. Бактеріальне забрудненням молока, яке було охолоджене і зберігалось 1 добу за температури $4^{\circ} \mathrm{C}$ менше в 4,6 рази $(\mathrm{P}<0,01)$, ніж молока неохолодженого, дослідженого через 3 год. після доїння (224,8 \pm 37,0 тис. КУО/мл). Це доказує, що відповідність бактеріального забруднення молока до європейських вимог (до 100 тис. КУО/мл) можлива тільки при охолодженні молока в потоці до $4{ }^{\circ} \mathrm{C}$ відразу після доїння і зберігання його у танку-охолоджувачі.

Вимоги у Франції до коров'ячого молока жорсткіше ніж за Директивою Свросоюзу стосовно мікробного забруднення і кількості соматичних клітин. Наприклад, якщо молоко не було зібрано впродовж 2-х годин після доїння, його потрібно охолодити до температури $8{ }^{\circ} \mathrm{C}$ або нижче, чи $6^{\circ} \mathrm{C}$ і нижче, якщо збирання продовжують більше доби (Yatsenko et al., 2016; Reglament (JeS) № 853/2004). Але вимога для фермерів Франції - у танках-охолоджувачах температура молока повинна бути не більше $5^{\circ} \mathrm{C}$. Взагалі, за Директивою Євросоюзу мікробне обсіменіння коров'ячого молока допускається до 100 тис/мл, але за французькими вимогами - до 50 тис/мл. За європейською вимогою кількість соматичних клітин повинна бути $\leq 400$ тис/мл, але у Франції цей рівень $\leq$ 250 тис/мл у коров'ячому молоці. 


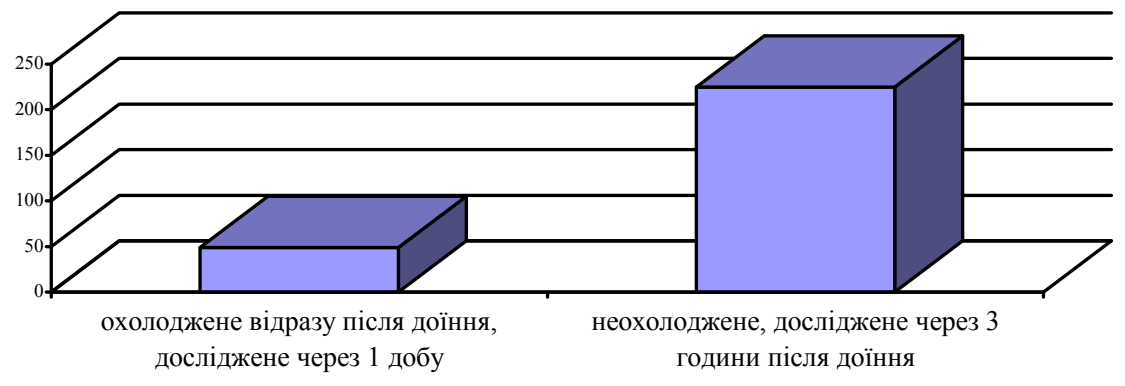

\section{Рис.1. Бактеріальне забруднення коров'ячого молока в залежності від терміну і температури зберігання, $\times 10^{3}$ КУО/мл, $n=5$}

\section{Висновки}

Проби можуть бути доставлені у лабораторію протягом 2-3 годин за температури $2,10,20{ }^{\circ} \mathrm{C}$, якщо молоко відразу після доїння охолоджується і зберігається в танку за температури $4{ }^{\circ} \mathrm{C}$.

Бактеріальне забрудненням молока, яке було охолоджене і зберігалось 1 добу за температури $4^{\circ} \mathrm{C}$ менше в 4,6 рази ( $\mathrm{P}<0,01)$, ніж молока неохолодженого, дослідженого через 3 години після доїння. Це доказує, що відповідність бактеріального забруднення молока до європейських вимог (до 100 тис. КУО/мл) можлива тільки при охолодженні молока в потоці до $4{ }^{\circ} \mathrm{C}$ відразу після доїння i зберігання його у танкуохолоджувачі.

Перспективи подальших досліджень. Подальше вивчення впливу різних факторів (раціону годівлі, дегельмінтизації) на показники якості та безпеки козиного молока. Також планується оцінювання різних методів визначення соматичних клітин у козиному молоці.

\section{Бібліографічні посилання}

Yatsenko, I. V., Bogatko, N. M., Bukalova, N. V. ta in. (2016). Gigiena moloka i molochnikh produktiv. CHastina 1. Gigiena moloka: Pidruchnik, KHarkiv: «Disa plyus» (in Ukrainian).

Yakubchak, O.M., Olijnik, L.V., Mel'nichuk, S.D. ta in. (2012). Praktikum z veterinarno-sanitarnoï ekspertizi z osnovami tekhnologiï ta standartizatsiï kharchovikh produktiv. Kiïv, «Kompaniya «Bioprom» (in Ukrainian).

Sánchez, A., Sierra, D., Luengo, C., Corrales, J., Morales, C., Contreras, A., Gonzalo, C. (2005). Influence of storage and preservation on Fossomatic cell count and composition of goat milk. Journal of Dairy Science. 88, 3095-3100.

Dutra, C., Svierk, B., Ribeiro, M., Pinto, A., Zanela, M., Schmidt, V. (2014). Effects of cold storage on the quality of goat milk. Arquivos do Instituro Biologico, São Paulo. 81(1), 36-42.

Sierra, D., Sánchez, A., Contreras, A., Luengo, C., Corrales, J., Fe, C., Guirao, I., Morales, C., Gonzalo,
C. (2009). Short communication: effect of storage and preservation on total bacterial counts determined by automated flow cytometry in bulk tank goat milk. Journal of Dairy Science. 92(10), 4841-4845.

Mashkin, M.I., Mogutova, V.F., Litvin, T.O. (2013). Rozrobka biotekhnologiï pitnogo pasterizovanogo moloka $\mathrm{z}$ pokrashhenimi funktsional'nimi vlastivostyami. Zbirnik naukovikh prats' VNAU. 3(73), 185-191. (in Ukrainian).

Mohamed, H., Zubeir, I., Fadlelmoula, A. (2016). Variation of microbial load of sudanese nubian goat' milk as affected by lactoperoxidase enzyme system, stage of lactation and storage temperature. Research Journal of Microbiology. 11(2-3), 64-69.

Sanchez-Macias, D., Castro, N., Moreno-Indias, I., Morales-delaNuez, A., Briggs, H., Argüello, A. (2010). The effects of storage temperature on goat milk somatic cell count using the DeLaval counter. Tropical Animal Health and Production. 42(7), 13171320 .

Zazhars'ka, N. M., Ryaba, A. O. (2016). Sanitarna yakist' kozinogo moloka za vikoristannya gomeopatichnikh zasobiv dlya doïnnya. Naukovo-tekhnichnij byuleten' Derzhavnogo naukovo-doslidnogo kontrol'nogo institutu veterinarnikh preparativ ta kormovikh dobavok ta Institutu biologiï tvarin. 72-77 (in Ukrainian).

Zazharskaya, N.N. (2015). Organizatsiya raboty i provedenie analizov v laboratorii moloka vo Frantsii: Mat. mezhdunarodnoj konf. Innovatsionnoe razvitie agrarnoj nauki i obrazovaniya: mirovaya praktika i sovremennye prioritety. Gyandzha (Azerbajdzhan). 480-484 (in Russian).

Ladika, L.M. SHapovalov, S.O., Fotina, T.I. [ta in.]. (2014). Fiziko-khimichnij sklad kozyachogo moloka za umov provedennya monitoringovikh doslidzhen' jogo yakosti na Skhodi Ukraïni. Naukovo-tekhnichnij byuleten' institutu biologiï tvarin i derzhavnogo naukovo-doslidnogo kontrol'nogo institutu vetpreparativ ta kormovikh dobavok. 27-34 (in Ukrainian). 